\title{
Assessment of Water Quality Index and Heavy Metal Contamination in Active and Abandoned Iron Ore Mining Sites in Pahang, Malaysia
}

\author{
Zafira Madzin ${ }^{1, *}$, Faradiella Mohd Kusin ${ }^{1,2}$, Fasihah Mohd Yusof ${ }^{1}$, and Siti Nurjaliah \\ Muhammad $^{1}$ \\ ${ }^{1}$ Department of Environmental Sciences, Faculty of Environmental Studies, Universiti Putra \\ Malaysia, 43400 UPM Serdang, Malaysia \\ ${ }^{2}$ Environmental Forensics Research Centre (ENFORCE), Faculty of Environmental Studies, \\ Universiti Putra Malaysia, 43400 UPM Serdang, Malaysia
}

\begin{abstract}
The composition of heavy metals in water and surface soils of iron ore mining sites were investigated to evaluate on the potential occurrence of heavy metal contamination. Physico-chemical characteristics of the waters were also investigated to determine the current status of water quality index (WQI) of the sites. Samples of water and surface soils of active mine (Kuala Lipis) and abandoned mine (Bukit Ibam) in Pahang were collected at four locations, respectively. The physico-chemical parameters measured for WQI were $\mathrm{pH}$, dissolved oxygen, biological oxygen demand (BOD), chemical oxygen demand (COD), suspended solids (SS), and ammoniacal nitrogen (AN). The water quality parameters were classified according to the Department of Environment (DOE) water quality classification. The study revealed that most of the sites in Bukit Ibam and Kuala Lipis were categorized as clean to slightly polluted. On the other hand, heavy metal analysis in water showed that aluminium and manganese level in both sites have exceeded the allowable limits for raw and treated water standards by the Ministry of Health. For heavy metal compositions in soils showed most of the heavy metal concentrations were below the recommended guideline values except for lead, arsenic, zinc and copper.
\end{abstract}

\section{Introduction}

Pahang was reported as the top producer for most minerals in Malaysia [1]. However, there are several abandoned and active mining sites in Pahang that are not properly managed and could possibly become the source for water pollution. Mining industry has become a major economic contribution to the world. Several minerals such as iron ore, gold ore, sand ore and bauxite are known as the main source of energy and materials. From metal to non-metallurgic minerals, both are gradually extracted and exploited to meet the economic demands. Hence, this industry may also bring undesirable impacts to the world especially on the environmental aspects. Over exploitation of these minerals has cause

\footnotetext{
*Corresponding author: faradiella@upm.edu.my
} 
excessive solid waste and wastewaters to remain untreated and discard hazardous substances to the biodiversity [2-6]. These toxic discharges which are the heavy metals and other trace elements can be uncontrollably percolated and penetrated to the soil and creating water and groundwater pollutions. A long-term exposure to heavy metals can be carcinogenic, affecting central and peripheral nervous system and circulatory effects [7]. High concentrations of heavy metals can cause potential risk to human health as heavy metal is easy to accumulate into the living tissues [8].

One of the serious problem that could arise from heavy metal contamination in mining industries is acid mine drainage (AMD). Acid mine drainage have resulted in serious pollution problem on surface or groundwater as well as in soil. AMD is acidic water that has high metal content formed by the reaction between oxygen and water in sulphide bearing minerals [9]. Hence, the objective of this research is to investigate the composition of heavy metals in water and surface soils of iron ore mining sites in Kuala Lipis and Bukit Ibam.

\section{Materials and method}

\subsection{Sampling sites}

The study was conducted at Kuala Lipis and Bukit Ibam where both are iron-ore mining sites. Four sampling locations were identified in Kuala Lipis while another four sampling sites were in Bukit Ibam. These iron mines are one of the top producers of iron in the state of Pahang as early as in the 1960s [10]. The Bukit Ibam abandoned mines were actively mined in 1960 and the iron mining activities have left hectares of abandoned ponds which have no buffer zone and the water can easily overflow to the river nearby during raining season. The iron ore mines in Kuala Lipis are still being mined actively in discrete areas but heavily connected to water stream (rivers). The sampling was carried out in June 2015 at location sites as shown in Fig. 1. Most of iron mining sites consist of Paleozoic and Mesozoic sedimentary rock sequence, which are dominated with limestone and shale then followed by volcanic and pyroclastic rocks [11].
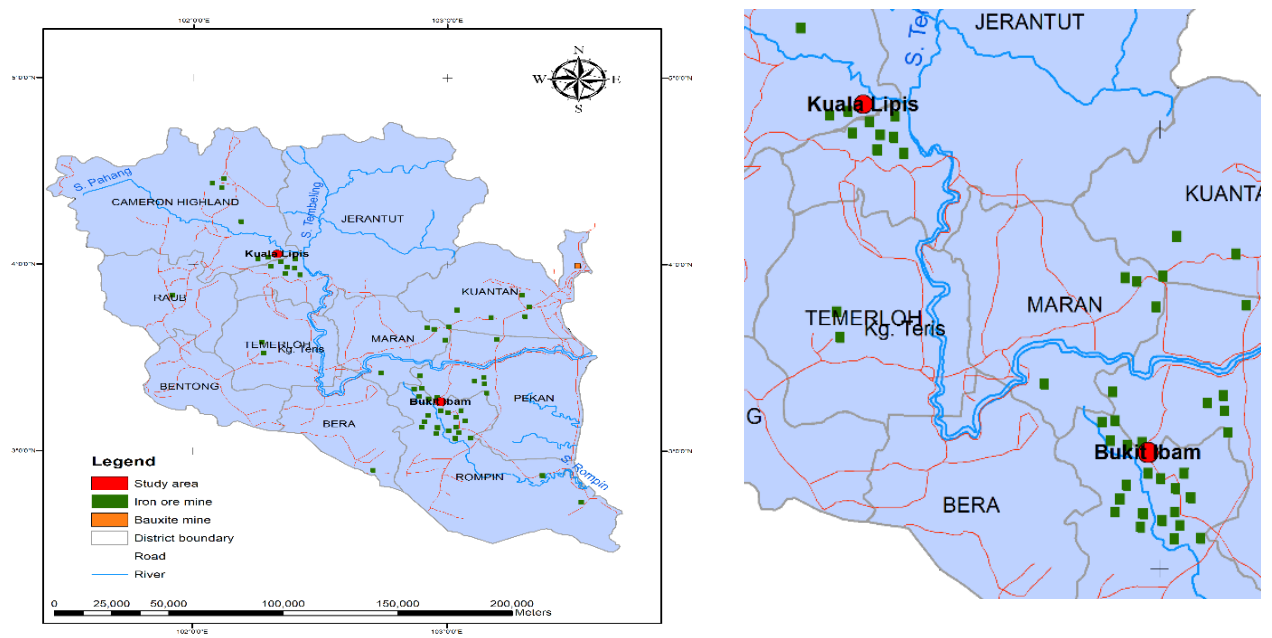

Fig. 1. Map of mining study sites of Bukit Ibam, Kuala Lipis (Mineral and Geoscience Department Malaysia, 2014) 


\subsection{Sampling of water and surface soil}

\subsubsection{Sampling of surface soil and water}

Water samples were collected with great care to prevent contamination. Water samples for BOD, COD, TSS and AN were collected at site and brought back to the laboratory for analysis. Samples for COD and $\mathrm{AN}$ were acidified with $\mathrm{H}_{2} \mathrm{SO}_{4}$ until $\mathrm{pH}<2$, whilst samples for BOD were analysed within 48 hours after sampling. Water $\mathrm{pH}$ and $\mathrm{DO}$ were measured on-site using Ultrameter 6P and a DO meter, respectively. Water samples for metal analysis were collected using $150 \mathrm{ml}$ clean polyethylene container and were preserved with $1 \% \mathrm{v} / \mathrm{v}$ $\mathrm{HNO}_{3}$ until $\mathrm{pH}<2$. The water samples were filtered upon arrival to the laboratory and were analyzed using ICP-OES for metal elements ( $\mathrm{Cu}, \mathrm{Fe}, \mathrm{Mn}, \mathrm{Pb}, \mathrm{Zn}, \mathrm{Cd}$, As, Cr, Ni and Al).

Samples of surface soils were collected at both active and abandoned iron mining sites. At each site, the soil were scooped into a clean polyethylene bags and then sealed and labelled. The sample of soils were kept in an icebox and brought back to the laboratory for further analysis. In the laboratory, all of the soil samples were oven dried for 3 hours at $105^{\circ} \mathrm{c}$, pulverized into fine powder using mortar and pestle and then sieved using $2 \mathrm{~mm}$ test sieve [12]. The preparation of samples was conducted accordingly to the USEPA (USEPA, 1996) method for heavy metal analysis. To extract heavy metal, acid digestion technique was used where $1.0 \mathrm{~g}$ of dry soil samples were digested with aqua regia extraction method, using hydrochloric acid and nitric acid (ratio of 3:1) [10]. Then, the samples were analyzed for heavy metal $(\mathrm{Fe}, \mathrm{Pb}, \mathrm{Cr}, \mathrm{Cd}, \mathrm{Zn}, \mathrm{Cu}, \mathrm{Mn}, \mathrm{As}, \mathrm{Cd}, \mathrm{Cr}$ and $\mathrm{Ni}$ ) using inductively coupled plasma-optical emission spectrometer (ICP-OES).

\subsubsection{Water quality parameters assessment}

The Department of Environment (DOE) uses water quality index (WQI) to measure the water quality status in Malaysia. WQI serves as an indicator to discover the pollution levels and environmental basis in designation of classes for the beneficial use of National Water Quality Standards (NWQS) in Malaysia. It consists of series of sub-indices which are then compared to the given rating curve, combined and resulting in the final index [13]. The WQI index range from 0-100 where Class III, 0-59 (polluted), Class II, 60-80 (slighty polluted), and Class I, 81-100 (clean). The sub-indices that were specified to calculate WQI are the concentration of biological oxygen demand (BOD), chemical oxygen demand (COD), dissolved oxygen (DO), ammoniacal nitrogen (AN), total suspended solids (TSS) and $\mathrm{pH}[14,15]$. Measurements of $\mathrm{pH}$ and $\mathrm{DO}$ were taken on-site whilst BOD, COD, TSS and $\mathrm{AN}$ were determined in the laboratory, and the WQI were calculated using equation $1[16]$

$$
\begin{gathered}
W Q I=(0.22 * S I D O)+(0.19 * S I B O D)+(0.16 * S I C O D)+(0.15 * S I A N) \\
+(0.16 * S I S S)+0.12 * S I P H)
\end{gathered}
$$

\section{Results and discussion}

\section{1 water quality assessment}

For WQI assessment, the DOE-WQI was calculated for all sampling locations. The results of the WQI were shown in Table 1. From the observation, it is found that the lowest WQI 
was at S2 in Kuala Lipis (67). In Kuala Lipis, the WQI calculated was found in the order of $\mathrm{S} 2<\mathrm{S} 4<\mathrm{S} 3<\mathrm{S} 1$ (lowest to highest). $\mathrm{S} 1$ is a discharge just outside the mining area. S2 is a stream around the mining site. S3 is another discharge near S2 while S4 is a discharge that is close to resident area. S1 was classified as class I (clean) while S2, S3 and S4 were in class II which indicate that the water is clean but need further treatment if used as a raw water alternative (NWQS).

While in Bukit Ibam, the DOE-WQI resulted in clean status for all the four sites. In order of arrangement from lowest to highest, WQI was found in the order of $\mathrm{S} 4<\mathrm{S} 1<\mathrm{S} 3<\mathrm{S} 2$. The highest value is 90 which is at $\mathrm{S} 2$ (a pond near mining site) and then $\mathrm{S} 3$ which is a discharge around the mining area. S1 is the river point nearest the iron mine and S4 is another discharge at the mining area. The Bukit Ibam mine site was the biggest iron mining site in Malaya during 1960s and was one of the largest mining site in Southeast Asia [10]. A study on the water quality status in Bukit Ibam found that the $\mathrm{pH}$ was acidic [9] and there is a potential of AMD (acid mine drainage) problem. Heavy metal contamination arising from mining industries has given tremendous harmful risk to the environment [17]. The clean status of water quality may be due to the fact that the mine has been left for more than 40 years and hence the heavy metal concentration have been decreased and segregated away through the surface and groundwater streams but also could be settled down and penetrated into the sediments [18].

Additionally, further water quality evaluation is required as WQI does not include major and trace element geochemistry to understand the behaviour of heavy metals in water [13]. It was concluded that there was no apparent contamination in the water quality for both mining sites observed as all the readings are below the standards given by the MOH and NWQS. Table 2 shows the heavy metal concentrations in water of both mining sites. From the concentration values in Kuala Lipis, all of the parameters are under the standard guidelines except for the value of $\mathrm{Mn}$ in both $\mathrm{S} 1$ and $\mathrm{S} 2 . \mathrm{Mn}$ is a common metalloid found in iron ore mines [19] and due to the alkaline condition of the water $\mathrm{pH}$, the $\mathrm{Mn}$ may not dissolved easily and remain in the water [20]. Such water are in concern because the Mn tends to stay in solution, and can be carried to downstreams and eventually into domestic waters. Whilst in Bukit Ibam, all parameters are still under standard limit except for Al and $\mathrm{Mn} . \mathrm{Al}$ is common in many ores including iron ore. $\mathrm{Al}$ is very hard to reduce and has been contributed to a lot of aquatic related pollutions [21].

\subsection{Sediment analysis}

Analyzing heavy metal concentrations in sediments/soils are an important reference indicator to water quality [22,23]. The values are compared with the UK Environment Agency standards (2008) and Canadian Counsils of Ministers of Environment (2011), due to the fact that Malaysia does not have its own standards for contaminated land. Table 2 shows the heavy metal compositions of the surface soils. Notwithstanding the WQI classification, it is interesting to note that in Kuala Lipis, all stations showed most of the heavy metal concentrations were below the recommended guideline values except for lead $(\mathrm{Pb})$, arsenic $(\mathrm{As})$ and copper $(\mathrm{Cu})$. As illustrated in Table 3, $\mathrm{S} 1$ showed $\mathrm{Pb}, \mathrm{Cu}$ and $\mathrm{As}$ which exceed the recommended values. S2 showed high content of $\mathrm{Cu}$ and As while S3 showed high concentrations of $\mathrm{Pb}$ and $\mathrm{Cu}$. Whilst in Bukitlbam abandoned mine, although the WQI status showed clean status, the heavy metal concentrations in the surface soils are high for all stations mainly $\mathrm{Pb}, \mathrm{Cu}, \mathrm{Zn}$ and As. As the mining sites are located at the oil palm plantation, apart from mining activities, the contribution of $\mathrm{Zn}$ in the agricultural soils might have contributed to the concentration of $\mathrm{Cu}$ in the soil. [21]. The concentrations or As has exceeded the allowable limit where the concentrations were the highest at S3 $(632.5 \mathrm{mg} / \mathrm{kg}), 268.5 \mathrm{mg} / \mathrm{kg}$ (S1), $194.5 \mathrm{mg} / \mathrm{kg}$ in $\mathrm{S} 2$ and $54 \mathrm{mg} / \mathrm{kg}$ in $\mathrm{S} 4$, compared to 5.9 
$\mathrm{mg} / \mathrm{kg}$ of the allowable limit by the Canadian Councils of Ministers of Environment (2011). The arsenic-containing minerals from the iron mine possibly mobilized during the mining activities and deposited to the sediments or soils and are still there even after 40 years. Therefore, it was found that several of these metals were at high concentration level and hence careful consideration has to be given upon potential remediation strategies.

With regard the effect on human health, heavy metal such as $\mathrm{Pb}$, in mines and smelters could lead to acute $\mathrm{Pb}$ poisoning where the symptoms are headache, abdominal pain and lead encephalopathy. Research found that a long term exposure of $\mathrm{Pb}$ could cause memory deterioration and diminished intellectual capacity [24], whereby too much $\mathrm{Cu}$ in liver cells is harmful and lead to liver damage and other symptoms that give serious on health. As is a well distributed metalloid occurring in metal rocks and also has been taken up in daily foods. Despite that, inorganic arsenic is acutely toxic and large exposure to arsenic could also give a harmful effect to the human bodies which gives severe disturbance to the nervous and gastrointestinal systems, and also gangrenous changes (black foot disease) as reported in Taiwan [25].

Table 1.Physico-chemical data of the waters

\begin{tabular}{|c|c|c|c|c|c|c|c|c|c|}
\hline Location & $\mathrm{pH}$ & $\begin{array}{c}\mathrm{DO} \\
(\mathrm{mg} / \mathrm{L})\end{array}$ & $\begin{array}{c}\text { TSS } \\
(\mathrm{mg} / \mathrm{L})\end{array}$ & $\begin{array}{c}\text { BOD } \\
(\mathrm{mg} / \mathrm{L})\end{array}$ & $\begin{array}{c}\text { COD } \\
(\mathrm{mg} / \mathrm{L})\end{array}$ & $\begin{array}{c}\mathrm{AN} \\
(\mathrm{mg} / \mathrm{L})\end{array}$ & WQI & Class & Status \\
\hline \multicolumn{10}{|l|}{$\begin{array}{l}\text { Kuala Lipis (iron } \\
\text { ore mining) }\end{array}$} \\
\hline $\begin{array}{l}\text { S1-Kuala Lipis } \\
\text { discharge }\end{array}$ & 7.9 & 3.76 & 0.014 & 6.7 & 0.67 & 0.2 & 81 & I & Clean \\
\hline $\begin{array}{l}\text { S2- Kuala } \\
\text { LipisdischargeII }\end{array}$ & 7.88 & 4.11 & 0.011 & 5.4 & 148.33 & 0.15 & 67 & II & $\begin{array}{l}\text { Slightly } \\
\text { polluted }\end{array}$ \\
\hline $\begin{array}{l}\text { S3- Kuala } \\
\text { LipisdischargeIII }\end{array}$ & 7.86 & 2.75 & 0.022 & 3.6 & 2 & 0.2 & 78 & II & $\begin{array}{l}\text { Slightly } \\
\text { polluted }\end{array}$ \\
\hline $\begin{array}{l}\text { S4- Kuala Lipis } \\
\text { discharge }\end{array}$ & 7.99 & 2.3 & 0.111 & 4.7 & 6.67 & 0.2 & 72 & II & $\begin{array}{l}\text { Slightly } \\
\text { polluted }\end{array}$ \\
\hline \multicolumn{10}{|c|}{$\begin{array}{c}\text { Bukit Ibam (abandoned iron } \\
\text { ore mine) }\end{array}$} \\
\hline $\begin{array}{l}\text { S1- Bukit Ibam } \\
\text { (river) }\end{array}$ & 6.99 & 5.31 & 0.035 & 5.4 & 2.33 & 0.25 & 85 & I & Clean \\
\hline $\begin{array}{l}\text { S2- Bukit Ibam } \\
\text { abandoned mine } \\
\text { pond }\end{array}$ & 6.45 & 4.94 & 0.028 & 3.5 & 1.33 & 0.11 & 90 & I & Clean \\
\hline $\begin{array}{l}\text { S3- Bukit Ibam } \\
\text { abandoned mine II } \\
\text { discharge }\end{array}$ & 7.96 & 5.25 & 0.004 & 4.6 & 3.33 & 0.42 & 86 & I & Clean \\
\hline $\begin{array}{l}\text { S4- Bukit Ibam } \\
\text { abandoned } \\
\text { discharge }\end{array}$ & 7.76 & 5.02 & 0.068 & 4.7 & 7 & 0.38 & 84 & I & Clean \\
\hline $\begin{array}{l}\text { MOH (2009) } \\
\text { (untreated raw } \\
\text { water) }\end{array}$ & $5.5-9.0$ & ** & $* *$ & $* *$ & $* *$ & $* *$ & & & \\
\hline $\begin{array}{l}\text { MOH }(2009) \\
\text { (treated water) }\end{array}$ & $6.5-9.0$ & $* *$ & $* *$ & $* *$ & $* *$ & $* *$ & & & \\
\hline $\begin{array}{l}\text { WHO (2009) \& } \\
\text { USEPA (2009) }\end{array}$ & $6.8-9.2$ & $* *$ & $* *$ & $* *$ & $* *$ & $* *$ & & & \\
\hline $\begin{array}{l}\text { EU drinking water } \\
\text { standards (EU } \\
\text { directive } 98 / 83 / \mathrm{EC}\end{array}$ & $6.5-9.5$ & $* *$ & $* *$ & $* *$ & $* *$ & $* *$ & & & \\
\hline
\end{tabular}


Table 2. Heavy metal concentrations in water

\begin{tabular}{|c|c|c|c|c|c|c|c|c|c|}
\hline Location & $\mathrm{Cu}$ & $\mathrm{Fe}$ & $\mathrm{Mn}$ & $\mathrm{Pb}$ & $\mathrm{Zn}$ & $\mathrm{Cd}$ & $\mathrm{Cr}$ & $\mathrm{Ni}$ & $\mathrm{Al}$ \\
\hline \multicolumn{10}{|c|}{$\mathrm{mg} / \mathrm{L}$} \\
\hline $\begin{array}{l}\text { Kuala Lipis (iron } \\
\text { ore mining) }\end{array}$ & & & & & & & & & \\
\hline $\begin{array}{l}\text { S1-Kuala Lipis } \\
\text { discharge }\end{array}$ & 0.003 & 1.299 & 0.297 & $<\mathrm{LOD}$ & 0.008 & $<$ LOD & $<\mathrm{LOD}$ & $<\mathrm{LOD}$ & 0.13 \\
\hline S2- Kuala & 0.002 & 0.377 & 0.77 & $<\mathrm{LOD}$ & 0.005 & $<$ LOD & $<\mathrm{LOD}$ & $<\mathrm{LOD}$ & 0.084 \\
\hline & & & & & & $<\mathrm{IOD}$ & $<\mathrm{IOD}$ & $<$ IOD & 0079 \\
\hline LipisdischargeIII & 0.005 & 0.286 & 0.106 & $<$ LOD & 0.005 & $<$ LUD & $<$ LUD & $<$ LUD & 0.079 \\
\hline $\begin{array}{l}\text { S4- Kuala Lipis } \\
\text { discharge }\end{array}$ & 0.006 & 0.111 & 0.01 & $<\mathrm{LOD}$ & 0.003 & $<\mathrm{LOD}$ & $<\mathrm{LOD}$ & $<\mathrm{LOD}$ & 0.16 \\
\hline \multicolumn{10}{|l|}{$\begin{array}{l}\text { Bukit Ibam (iron } \\
\text { ore mining) }\end{array}$} \\
\hline $\begin{array}{l}\text { S1- Bukit Ibam } \\
\text { (river) }\end{array}$ & 0.025 & 0.104 & 1.027 & $<\mathrm{LOD}$ & 0.642 & 0.001 & $<\mathrm{LOD}$ & $<\mathrm{LOD}$ & 0.345 \\
\hline $\begin{array}{l}\text { S2- Bukit Ibam } \\
\text { abandoned mine }\end{array}$ & 0.002 & 0.069 & 0.068 & $<\mathrm{LOD}$ & 0.044 & 0.001 & $<\mathrm{LOD}$ & $<\mathrm{LOD}$ & 0.19 \\
\hline $\begin{array}{l}\text { S3- Bukit Ibam } \\
\text { abandoned mine II }\end{array}$ & 0.011 & 0.039 & 0.287 & $<\mathrm{LOD}$ & 0.017 & 0.002 & $<\mathrm{LOD}$ & $<\mathrm{LOD}$ & 0.089 \\
\hline $\begin{array}{l}\text { S4- Bukit Ibam } \\
\text { abandoned (sand } \\
\text { mine) }\end{array}$ & 0.006 & 0.039 & 0.104 & 0.005 & 0.008 & $<\mathrm{LOD}$ & $<\mathrm{LOD}$ & $<\mathrm{LOD}$ & 0.054 \\
\hline $\begin{array}{l}\text { MOH (2009) } \\
\text { (untreated raw } \\
\text { water) }\end{array}$ & 1.00 & 1.00 & 0.20 & 0.10 & 5.00 & 0.005 & 0.05 & $* *$ & $* *$ \\
\hline $\begin{array}{l}\text { MOH (2009) } \\
\text { (treated water) }\end{array}$ & 1.00 & 0.30 & 0.10 & 0.05 & 5.00 & 0.005 & 0.05 & $* *$ & 0.2 \\
\hline $\begin{array}{l}\text { WHO (2009) \& } \\
\text { USEPA (2009) }\end{array}$ & 1.00 & 0.30 & 0.05 & 0.05 & 5.00 & 0.01 & 0.05 & 0.02 & 0.2 \\
\hline $\begin{array}{l}\text { EU drinking water } \\
\text { standards (EU } \\
\text { directive } 98 / 83 / \mathrm{EC}\end{array}$ & 2.00 & 0.25 & 0.05 & 0.01 & $* *$ & 0.005 & 0.05 & 0.02 & \\
\hline
\end{tabular}

\#Data presented are mean data $(n=)$ for all parameters

$* *$ not specified 
Table 3. Heavy metal composition of the surface soils

\begin{tabular}{|c|c|c|c|c|c|c|c|c|c|}
\hline \multirow{2}{*}{ Station } & $\mathrm{Pb}$ & $\mathrm{Cu}$ & $\mathrm{Zn}$ & $\mathrm{Mn}$ & $\mathrm{Fe}$ & As & $\mathrm{Cd}$ & $\mathrm{Cr}$ & $\mathrm{Ni}$ \\
\hline & \multicolumn{9}{|c|}{$(\mathrm{mg} / \mathrm{kg})$} \\
\hline $\begin{array}{l}\begin{array}{l}\text { Kuala Lipis } \\
\text { (iron ore }\end{array} \\
\text { mining) } \\
\text { S1-Kuala Lipis } \\
\text { discharge }\end{array}$ & 63.5 & 97 & 106 & 2127.7 & 128550 & 20.5 & 0.37 & 7.89 & 1.45 \\
\hline $\begin{array}{l}\text { S2- Kuala } \\
\text { LipisdischargeII }\end{array}$ & 32 & 165.5 & 116 & 2213 & 127350 & 465 & 0.42 & 6.94 & 2.99 \\
\hline $\begin{array}{l}\text { S3- Kuala } \\
\text { LipisdischargeIII } \\
\text { Bukit Ibam } \\
\text { (abandoned } \\
\text { iron ore mine) }\end{array}$ & 72.5 & 67.5 & 93 & 2737 & 68200 & 5 & 0.063 & 9.34 & 4.36 \\
\hline $\begin{array}{l}\text { S1- Bukit Ibam } \\
\text { (river) }\end{array}$ & 288.5 & 1798.5 & 1512.5 & 4478 & 134500 & 268.5 & 0.029 & 11.07 & 4.33 \\
\hline $\begin{array}{l}\text { S2- Bukit Ibam } \\
\text { abandoned mine }\end{array}$ & 2195 & 1482.5 & 1542.5 & 4341 & 119600 & 194.5 & 0.06 & 0.24 & 7.96 \\
\hline $\begin{array}{l}\text { S3- Bukit Ibam } \\
\text { abandoned mine } \\
\text { II }\end{array}$ & 344.5 & 2845 & 1691 & 5285 & 211050 & 632.5 & 0.04 & 5.96 & 1.34 \\
\hline $\begin{array}{l}\text { S4- Bukit Ibam } \\
\text { abandoned (sand } \\
\text { mine) }\end{array}$ & 96.5 & 67.5 & 1682 & 920.5 & 75900 & 54 & 0.042 & 2.47 & 1.99 \\
\hline $\begin{array}{l}\text { Canadian } \\
\text { Council of } \\
\text { Ministers of } \\
\text { Environment } \\
(2001)\end{array}$ & 35 & 35.7 & 123 & $* *$ & $* *$ & 5.9 & 0.6 & 37.3 & 18 \\
\hline $\begin{array}{l}\text { UK } \\
\text { Environment } \\
\text { Agency (2008) }\end{array}$ & & & & & & & & & \\
\hline TEL - Threshold & 35 & 36.7 & 123 & $* *$ & $* *$ & 5.9 & 0.596 & 37.3 & 18 \\
\hline $\begin{array}{l}\text { Effects Level } \\
\text { PEL - Predicted } \\
\text { Effects Level } \\
\text { Background }\end{array}$ & 91.3 & 197 & 315 & $\begin{array}{c}* * \\
400\end{array}$ & $* *$ & 17 & 3.53 & $* *$ & $* *$ \\
\hline
\end{tabular}

\#Data presented are mean data $(n=)$ for all parameters

**not specified

\section{Conclusion}

In this study, the water quality index have been calculated for both active and abandoned mining sites studied in Pahang. According to DOE-WQI classification, the WQI of the sites range from Class I (clean) to Class II (slightly polluted) for both Kuala Lipis (active) and Bukit Ibam (abandoned) mining sites. Although the water quality shows no apparent contamination, further water quality evaluation were conducted to measure the heavy metal concentration. From the heavy metal compositions in water, $\mathrm{Mn}$ and $\mathrm{Al}$ parameters have exceeded the allowable limits for raw water in both sites respectively. On the other hand, it was found that the heavy metal concentrations in surface soils are below the recommended guidelines values except for $\mathrm{Cu}, \mathrm{Pb}, \mathrm{Zn}$ and $\mathrm{As}$ in most of the sites. Despite the findings from this study, it is recommended that further studies and monitoring 
should be conducted to assess long term impact of these heavy metals on the quality of river ecosystem and on human health.

The authors would like to give a special acknowledgement to the State of Pahang Government for giving permission to enter the site. The preliminary results presented here are only for the sake of learning and the results here are not certified by any registered analytical chemists.

\section{References}

[1] A. Ab Majid, H. Mohamed Shaharudin, S. Alias, E. Adnan, A. I. Ali Hassan, M Z. Ali, Malaysia mining industry by Minerals and geoscience department Malaysia,81,(2013)

[2] M. Benvenuti, I. Mascaro, P. Lattanzi, P. Parrini and G. Tanelli, Minewaste dumps and heavy metal pollution in abandoned mining District of Boccheggiano Southern Tuscany, Italy. Environmental Geology,30, 238-243,(1997)

[3] R. Asklundand B. Eldvall, Contamination of water resources in Tarkwa mining area of Ghana. Department of Engineering Geology, Lund University, Sweden, (2005).

[4] S. Wang andC.N Mulligan, Occurrence of Arsenic contamination in Canada: Sources behavior and distribution. Science of the total Environment, 366, 701-721,(2005)

[5] M. C. Navorro, C. Perez-Sirvent, M.J. Martinez-Sainchez, J. Vidal, P.J. Tovar and J. Bech Abandoned mine sites as a source of contamination by heavy metals: A Case study in a Semi-Arid Zone. J. of Geochemical Exploration, 96, 183-193,(2007)

[6] P., Schwab, D.Zhu, and M.K.Banks, Heavy metal leaching from mine tailings as affected by organic amendments. 98, 2935-2941,(2007)

[7] Z. Madzin, M. F. Shai-in, F. M. Kusin, Comparing heavy metal mobility in active and abandoned mining sites at Bestari Jaya, Selangor, 30, 232-237,(2015)

[8] W.S. Wan Ngah and M.A. Hanafiah,Removal of heavy metal ions from wastewater by chemically modified plant wastes as adsorbents: a review, Bioresource Technology, 99(10), 3935-3948,(2007)

[9] Kumar, A., Mining contractors and engineers, 33, (2013).

[10]S. M. Diami, F. M. Kusin, Z. Madzin, Potential ecological and human health risk of heavy metals in surface soils associated with iron ore mining in Pahang, Malaysia. Env. Sci.Pollut. Res.,(2016)

[11]W. Dzick and R.Carlson, Monument Mining Limited: Mengapur Project, Pahang State, Malaysia. Project No.V1165, Amended Technical Report, Vancouver Canada, 75,(2012)

[12]W. Z, Wan Yaacob and N.S. Mohd Pauzi, Acid mine drainage and heavy metals contamination at abandoned and active mine sites in Pahang, Bulletin of the Geological Society of Malaysia, 55, 15 - 20, (2009)

[13]F. M. Kusin, M. S. M Zahar, S.N. Muhammad, N. D. Mohamad, Z.M. Zin, S.M. Sharif, Hybrid off-river augmentation system as an alternative raw water resource: the hydrogeochemistry of abandoned mining ponds, Environ. Earth Sci.,75(3), 1-15, (2016)

[14]N,Mustapha,Indices for water quality in a river, Master's thesis, Asian Institute of Technology, Bangkok, (1981)

[15]M.A. Haque, Y.F. Huang, T.S. Lee, Seberang Perai rice scheme irrigation water quality assessment. J. Institution of Engineers Malaysia,71, 42-49,(2010).

[16] Department of Environment Malaysia(DOE), Interim National Water Quality Standards for Malaysia. Kuala Lumpur, (2008)

[17]D.B. Johnson, K.B. Hallberg, Acid mine drainage remediation options: a review. Science of the total Environment, 338, 3-14,(2005)

[18]L,B.Clarke, Coal Mining and Water Quality. London7 IEA Coal Research, 99, (1995) 
[19] K.B Krauskopt, Separation of manganese from iron in sedimentary process,12(61), 84, (1957)

[20]B.G. Lottermoser, Mine wastes, characterization, treatment and environmental impacts, Springer, Berlin, Germany,108, (2007)

[21]B.O. Rosseland, T.D. Eldhuset, M. Staurnes Environmental effects of aluminium, Environ. Geochem. Health, 12(1-2), 17-27, (1990)

[22] Y.Z. Chen, H. Yang, Z.K. Zhang, M.Z.Qin, F. Jin, J.J. Lu, Application of equilibrium partitioningapproach to the derivation of sediment quality guidelines for metals in Dianchi Lake. Pedosphere, 17(3), 284-294,(2007)

[23]F.M. Kusin, A review of the importance of hydraulic residence time on improved design of mine water treatment systems, World Appl. Sci., 26(10), 1316-1322, (2013)

[24]F.M.K usin, S.N. Muhammad, M.S.Md.Zahar, M. Zafira, Integrated river basin management: incorporating the use of abandoned mining pool and implication on water quality status. Desalin Water Treat. 57(60), (2016)

[25]L. Jarup, Hazards of heavy metal contamination. Bri Med Bull, 68, 167-182, (2003) 